\section{ISSN $1980-6477$}

Journal homepage: www.abms.org.br/site/paginas

Marcos Doniseti Michelotto ${ }^{1}()_{)}$, Willians Césa Carrega $^{2}$, Aildson Pereira Duarte ${ }^{3}$ e Rogério Soares de Freitas ${ }^{4}$.

(1)Agência Paulista de Tecnologia dos Agronegócios, Pólo Regional de Desenvolvimento dos Agronegócios do Centro Norte.Brasil. E-mail: michelotto@apta.sp.gov.br;

(2)Departamento de Produção Vegetal, FCAV/ Unesp, Jaboticabal, SP, Brasil. E-mail: willianscesar@hotmail.com;

${ }^{(3)}$ Centro de Grãos e Fibras, IAC, Campinas, SP, Brasil.

E-mail: aildson@iac.sp.gov.br;

${ }^{(4)}$ Centro de Seringueira e Sistemas Agroflorestais, IAC, Votuporanga, SP, Brasil.

E-mail: freitas@iac.sp.gov.br.

$\bowtie$ Corresponding author

How to cite

MICHELOTTO, M. D.; CARREGA W. C. DUARTE, A. P.; FREITAS, R. S. Comparison of ear damage caused by caterpillar pests in transgenic $(B t)$ maize hybrids and conventiona maize hybrids. Revista Brasileira de Milho Sorgo, v. 19, e1099, 2020.

\section{HYBRIDS}

\begin{abstract}
The use of transgenic (Bt) maize hybrids has been an important tool to minimize ear damages caused by the caterpillar pests Helicoverpa zea and Spodoptera frugiperda (Lepidoptera: Noctuidae). The objective of this work was to evaluate ear damages caused by caterpillar pests in maize hybrids with $B t$ technologies and in their respective conventional versions (non- $B t$ ) for control of caterpillar pests that attack maize ears in the state of São Paulo, Brazil. Experiments were carried out in four regions of the state, in two summer crops (2009/10 and 2010/11), using a randomized block design with $6 \times 2$ factorial arrangements. The first factor was the hybrids and the second factor was the use or not of Bt technology. During harvesting, the percentage of damaged ears was evaluated and damage scores were attributed to a sample of 20 ears per plot. It was found that: (i) YieldGard and Total Liberty (both Cry 1Ab), Herculex (Cry 1F), VTPRO (Cry 1A.105 + Cry2Ab2) and Viptera (VIP3Aa20) technologies, regardless of the hybrid and the season crop, significantly reduce the ear damages and the percentage of damaged ears; (ii) hybrids expressing the Cry $1 \mathrm{Ab}$ protein are more damaged by caterpillar pests compared with other technologies; and (iii) there is great variability among hybrids when expressing toxins, even among those hybrids with the same Bt event.
\end{abstract}

Keywords: Bacillus thuringiensis, genetically modified organisms, integrated pest management, Zea mays.

\section{DANOS OCASIONADOS POR LAGARTAS}

\section{NA ESPIGA EM HÍBRIDOS DE MILHO TRANSGÊNICOS $(B t)$ EM COMPARAÇÃO COM SUAS VERSÕES CONVENCIONAIS}

Resumo - $\mathrm{O}$ uso de híbridos de milho transgênicos (Bt) tem sido uma ferramenta importante para minimizar os impactos causados pelas lagartas que ocorrem na espiga, Helicoverpa zea e Spodoptera frugiperda (Lepidoptera: Noctuidae). O objetivo deste trabalho foi avaliar os danos ocasionados por lagartas em espigas de híbridos de milho com tecnologias $B t$ 's e suas respectivas versões convencionais (não $B t$ `s) no controle das lagartas que atacam a espiga do milho no Estado de São Paulo, Brasil. Realizaram-se experimentos em quatro regiões do Estado, em duas safras de verão, nos anos 2009/10 e 2010/11, em um delineamento em blocos casualizados, em arranjos fatoriais $6 \times 2$, tendo como primeiro fator, os híbridos e o segundo fator, o uso ou não da tecnologia Bt. Durante a colheita do milho, avaliou-se a porcentagem de espigas danificadas e atribuiu-se notas de danos a uma amostra de 20 espigas por parcela. Verificou-se que: $(i)$ as tecnologias YieldGard e Total Liberty (ambas Cry 1Ab), Herculex (Cry 1F), VTPRO (Cry 1A.105+Cry2Ab2) e Viptera (VIP3Aa20), independente do híbrido e da safra, reduzem significativamente a porcentagem de espigas danificadas e os danos nas espigas; (ii) os híbridos que expressam a proteína Cry $1 \mathrm{Ab}$ são mais danificados pelas lagartas do que em outras tecnologias; e (iii) há grande variabilidade entre os híbridos ao expressarem as toxinas, mesmo entre aqueles híbridos com o mesmo evento $\mathrm{Bt}$

Palavras-chave: Bacillus thuringiensis, organismos geneticamente modificados, manejo integrado de pragas, Zea mays. 
The insect pests can cause losses of approximately US\$17.7 billion in the Brazilian agricultural production (Oliveira et al., 2014). In the maize crop, it is one of the main factors that can compromise grain quality and yield (Michelotto et al., 2017).

Among the main lepidopteran pests in maize, the following stand out: fall armyworm, Spodoptera frugiperda (J. E. Smith, 1797) (Lepidoptera: Noctuidae); sugarcane borer, Diatraea saccharalis (Fabricius, 1794) (Lepidoptera: Crambidae); and corn earworm, Helicoverpa zea (Boddie, 1850) (Lepidoptera: Noctuidae) (Duarte et al., 2007; Gallo et al., 2002). Recently, Santos et al. (2016) evaluated the development of the species Helicoverpa armigera (Hubner, 1805) (Lepidoptera: Nocuidae) in maize crop. This pest has also been recorded in soybean and cotton crops in Brazil since 2013 (Czepak et al., 2013; Specht et al., 2013). Among them, the corn earworm is considered a key pest in many crops and its presence has been reported in North America, South America, Central America and the Caribbean, Asia and Europe (Cabi, 2018). In the south of the United States, high pressure of $H$. zea has been occurring, for a long time, in a wide variety of cultivated and non-cultivated plants (Olmstead et al., 2016). In Brazil, it is regarded as one of the major pests, which may cause losses in yield and quality of many products. Silva et al. (2018) mentioned that the presence of H. zea, S. frugiperda and Euxesta spp. was one of the main causes of maize yield losses.

Bt technologies aim at reducing the impacts caused by insect pests in crops and minimizing the use of agrochemicals. In Brazil, the use of transgenic maize resistant to insects of the order Lepidoptera was allowed in 2007. In the 2016/17 crop season, the use of transgenic maize presented an adoption rate of $88.4 \%$; being $63.9 \%$ cultivated with IR/HT (insect resistant and herbicide tolerant) events, $20.7 \%$ with maize resistant to insects only, and $3.8 \%$ with technology tolerant to herbicide only (Céleres, 2018).

The first event characterized by expressing the insecticidal protein was Cry $1 \mathrm{Ab}$. Since then, other events with expression of different insecticidal proteins and even with more than one protein were commercially released for the control of insects of the order Lepidoptera (Michelotto et al., 2017b; CNTBio, 2018). Nowadays, among Bt toxins that attack lepidopteran pests, the following stand out: Cry1Ab, Cry1Ac, Cry1A.105, Cry1F, Cry2Ab2, Cry2Ae and Vip3A (Dively et al., 2016).

Although the use of maize hybrids with Bt technologies (Bacillus thuringiensis Berliner) is mainly intended to control fall armyworm, it can be a useful tool to control several other species such as the H. zea (Silva et al., 2018). However, there are few studies carried out in Brazil that compare the efficiency of the different Bt technologies in the control of caterpillar pests in maize ears. Moreover, damages caused by maize pests differ even among conventional cultivars (Ota et al., 2011; Moraes et al., 2015 and Michelotto et al., 2017b). Therefore, the 
hypothesis is that transgenic maize technologies can present variation in regard to damages caused by the corn earworm, depending on the variability among the hybrids when expressing toxins. Thus, the objective of this study was to evaluate the impacts of the use of maize hybrids with $\mathrm{Bt}$ technologies and their respective conventional (non-Bt) versions in the control of caterpillar pests in maize ears.

\section{Material and Methods}

The experiments were conducted in four locations in different regions of the state of São Paulo, during two summer crops (2009/10 and 2010/11). In the Northwest, the experiment was conducted in the municipality of Votuporanga (Rubber Tree \& Agroforestry Systems Research Center); in the North Central, in the municipality of Pindorama (Regional Research Center); in the Médio Paranapanema region, in the municipality of Cruzália; and in the East Central, in the municipality of Aguaí.

The experiments were installed in randomized block design, in a 6 x 2 factorial arrangement, with four replications. The first factor corresponded to the different commercial hybrids and the second factor consisted of transgenic (Bt) or conventional (non-Bt) versions. In the second year, the same experiment was replicated with a $6 \times 2$ factorial arrangement, including three new technologies released at the time. For these new technologies, a comparison was made between conventional and transgenic hybrids (Table 1).

The experimental plots consisted of eight rows of ten meters, spaced $0.8 \mathrm{~m}$ apart. The seeding density was between 55 and 57 thousand plants/ha for all hybrids in all experiments. Other cultural practices were applied according to notillage system requirements and recommendations for each region.

Products used consisted of non-Bt maize hybrids (30F35, DuPont Pioneer $\AA$; AG8088, Agroceres $\AA$; 2B710, Dow AgroSciences $\AA$; DKB390, Dekalb $\AA$; Impacto, Syngenta $\AA$, and Maximus, Syngenta $($ ) and genetically modified hybrids, resistant to insects of the order Lepidoptera, with the following technologies: Herculex (30F35 $\mathrm{H}$ and 2B710 HX hybrids), which express Cry1F protein; Yieldgard (30F35 Y, AG8088 YG and DKB390 YG), which express Cry $1 \mathrm{Ab}$ protein; Total Liberty (Impacto $\mathrm{TL}$ ), which also expresses Cry $1 \mathrm{Ab}$ protein; VTPRO (AG8088 VTPRO and DKB390-PRO), which express Cry1A.105 + Cry2Ab2 proteins; and Viptera (Maximus Vip), which expresses VIP3Aa20 protein (Table 1).

During the plant growth period, three sprayings of spinosad insecticide $\left(70 \mathrm{~mL}\right.$ p.c. ha ${ }^{-1}$ - Tracer () were applied to control fall armyworm in conventional hybrids in all locations, regardless of lower or higher incidence of the insect pest.

Although the presence of caterpillars had been verified in maize ears, they were not quantified and/or identified. Only ear damages were taken into consideration, regardless of which species was causing such damages. This 
procedure was chosen due to the differences in the plant maturation period (early and late maturity hybrids) and the possible interferences of the caterpillar species in ear infestations.

In order to evaluate ear damages caused by caterpillars, sampling was conducted using 20 ears per plot, from the two central rows, in the reproductive stages R3 (pasty grain) and R5 (hard farinaceous grain). During the evaluations, the number of ears damaged by caterpillars was determined and the percentage of damaged ears was calculated. After that, attack symptoms were rated and each ear received a damage score on a scale of 0 to 5, being: $0=$ no damages; $1=$ damages of up to $1.0 \mathrm{~cm}$ as from the ear tip; 2 $=$ between 1.1 and $2.0 \mathrm{~cm} ; 3=$ between 2.1 and $3.0 \mathrm{~cm} ; 4=$ between 3.1 and $4.0 \mathrm{~cm}$; and $5=$ damages extending over $4 \mathrm{~cm}$; based on scale developed by Carvalho (1980).

Data were analyzed using F-test (ANOVA) at a significance level of 5\%, and means were compared using Tukey's test at a significance level of 5\%. All analyses were made using Agroestat statistical software (Barbosa \& Maldonado, 2015).

\section{Results and Discussion}

Percentage of damaged ears and scores for ear damages due to caterpillar attack in the first year of evaluation - Summer Crop (2009/10)

In regard to the percentage of damaged ears and scores for ear damages by caterpillar, a significant difference was verified among the hybrids as to $\mathrm{Bt}$ technology (conventional vs transgenic). Interaction between the factors (hybrids versus technologies) was also significant in all evaluated regions, except in Cruzália, where no significant interaction was observed for the percentage of damaged ears (Table 2).

After analysis of the interaction between the factors: hybrids versus technologies (Table 3 ), it was observed that, in the conventional versions, the Impacto hybrid presented the lowest percentage of damaged ears when compared with the other hybrids in Aguaí, Pindorama and Votuporanga. The Maximus hybrid presented intermediate percentage of damaged ears in Aguaí and Pindorama, while the DKB390 hybrid was intermediate only in Pindorama. In Aguaí, there was no significant difference among the hybrids in the transgenic version $(\mathrm{Bt})$ for the percentage of damaged ears, which varied from $0.0 \%$ to $7.0 \%$. In Pindorama, the percentage of damaged ears varied from $0.0 \%$ to $32.0 \%$, and was lower in the Impacto TL hybrid and intermediate in the DKB390 YG hybrid, both expressing the Cry $1 \mathrm{Ab}$ protein. In Votuporanga, the ear infestation varied from $2.0 \%$ to $18.0 \%$, and was lower in the hybrids Impacto TL (Cry 1Ab) and Maximus Viptera (expressing the VIP3Aa20 protein).

When comparing the conventional and transgenic versions for each hybrid, significant differences were observed for all treatments. The transgenic version, when compared with the conventional version, provided the lowest percentages of damaged ears, reducing, on average, $88 \%, 86 \%, 99 \%, 79 \%, 88 \%$ and $91 \%$, 
Table 1 - Maize events, technology brands, toxins and non- $B t$ and $B t$ maize hybrids used in the experiments in summer crops.

\begin{tabular}{|c|c|c|c|c|c|}
\hline \multirow[b]{2}{*}{ Event } & \multirow[b]{2}{*}{ Technology } & \multirow[b]{2}{*}{$\begin{array}{l}\text { Genetic } \\
\text { Modification }\end{array}$} & \multirow[b]{2}{*}{ Toxin } & \multicolumn{2}{|c|}{ Hybrids } \\
\hline & & & & $\begin{array}{l}\text { Summer crop } \\
(2009 / 10)\end{array}$ & $\begin{array}{l}\text { Summer crop } \\
(2010 / 11)\end{array}$ \\
\hline Conventional & & Non-Bt & NT & AG8088 & AG8088 \\
\hline MON810 & Yieldgard ( & $\mathrm{Bt}$ & CrylAb & AG8088 YG & AG8088 YG \\
\hline MON89034 & VTPRO® & $\mathrm{Bt}$ & Cry1A.105 + Cry2Ab2 & - & AG8088 VTpro \\
\hline Conventional & & Non-Bt & NT & DKB390 & DKB390 \\
\hline MON810 & Yieldgard $®$ & $\mathrm{Bt}$ & CrylAb & DKB390 YG & DKB390 YG \\
\hline MON89034 & VTPRO® & $\mathrm{Bt}$ & Cry1A.105 + Cry2Ab2 & - & DKB390 PRO \\
\hline Conventional & & Non-Bt & NT & 2B710 & 2B710 \\
\hline TC1507 & Herculex ${ }^{\circledR}$ & $\mathrm{Bt}$ & Cry1F & 2B710 HX & 2B710 HX \\
\hline Conventional & & Non-Bt & NT & $30 \mathrm{~F} 35$ & $30 \mathrm{~F} 35$ \\
\hline MON810 & Yieldgard $®$ & $\mathrm{Bt}$ & CrylAb & $30 F 35 \mathrm{Y}$ & $30 F 35 \mathrm{Y}$ \\
\hline TC1507 & Herculex ${ }^{\circledR}$ & $\mathrm{Bt}$ & Cry1F & - & $30 \mathrm{~F} 35 \mathrm{H}$ \\
\hline Conventional & & Non-Bt & NT & Impacto & Impacto \\
\hline SYN-BT11 & Total Liberty ${ }^{\circledR}$ & $\mathrm{Bt}$ & CrylAb & Impacto TL & Impacto TL \\
\hline Conventional & & Non-Bt & NT & Maximus & Maximus \\
\hline MIR162 & Viptera ${ }^{\circledR}$ & $\mathrm{Bt}$ & VIP3Aa20 & Maximus Viptera & Maximus Viptera \\
\hline
\end{tabular}

NT: no toxin; -: not tested in that year.

Table 2 - Summary of the analysis of variance for percentage of damaged ears (\%E) and damage scores (DS), due to caterpillar attacks, for each hybrid (H) and technology $(\mathrm{T})$ of location in the state of São Paulo, in the summer crop (2009/10).

\begin{tabular}{cllllllll}
\hline & \multicolumn{2}{c}{ Aguaí } & \multicolumn{2}{c}{ Cruzália } & \multicolumn{2}{c}{ Pindorama } & \multicolumn{2}{c}{ Votuporanga } \\
\hline & \%E & \multicolumn{1}{c}{ DS } & \%E & DS & \%E & DS & \%E & DS \\
\hline F-test (H) & $8.42^{* *}$ & $2.94^{*}$ & $4.31^{* *}$ & $17.22^{* *}$ & $43.68^{* *}$ & $4.06^{* *}$ & $10.94^{* *}$ & $5.97^{* *}$ \\
F-test (T) & $967.43^{* *}$ & $560.17^{* *}$ & $654.80^{* *}$ & $422.74^{* *}$ & $760.77^{* *}$ & $214.93^{* *}$ & $1452.10^{* *}$ & $169.72^{* *}$ \\
F-test (H x T) & $3.07^{*}$ & $7.88^{* *}$ & $1.74^{\text {NS }}$ & $4.69^{* *}$ & $16.43^{* *}$ & $6.47^{* *}$ & $3.04^{*}$ & $3.56^{* *}$ \\
\hline C.V. (\%) & 22.30 & 24.71 & 23.79 & 18.92 & 18.26 & 23.65 & 19.39 & 30.00 \\
\hline
\end{tabular}

respectively, for the hybrids $30 \mathrm{~F} 35 \mathrm{Y}, 2 \mathrm{~B} 710$ HX, Impacto TL, AG8088 YG, DKB390 YG and Maximus Viptera, regardless of the region. In the present study, great variability was noted on each hybrid's response, depending on the $\mathrm{Bt}$ technology, thus corroborating the results found by Moraes et al. (2015) and Michelotto et al. (2017b), who verified different performances among the hybrids with regard to $S$. frugiperda attacks. 
Table 3 - Percentage of ears damaged by caterpillar attacks, for each hybrid and technology of location in the State of São Paulo, in the summer crop (2009/10).

\begin{tabular}{|c|c|c|c|c|}
\hline Hybrids & Non-Bt & $\mathrm{Bt}$ & F-test & $\%$ Red. \\
\hline \multicolumn{5}{|c|}{ Aguaí } \\
\hline $30 \mathrm{~F} 35$ & $47.0 \mathrm{AB} \mathrm{a}$ & $0.0 \mathrm{Ab}$ & $194.13 * *$ & 100 \\
\hline $2 \mathrm{~B} 710$ & $51.0 \mathrm{AB}$ a & $4.0 \mathrm{~A} \mathrm{~b}$ & $194.13 * *$ & 92 \\
\hline Impacto & $32.0 \mathrm{C} \quad \mathrm{a}$ & $0.0 \mathrm{Ab}$ & $89.99 * *$ & 100 \\
\hline AG8088 & $49.0 \mathrm{AB}$ a & $3.0 \mathrm{~A} \mathrm{~b}$ & $185.96 * *$ & 94 \\
\hline DKB390 & $52.0 \mathrm{~A} \quad \mathrm{a}$ & $7.0 \mathrm{Ab}$ & $177.96 * *$ & 87 \\
\hline Maximus & $41.0 \mathrm{BC} \quad \mathrm{a}$ & $1.0 \mathrm{Ab}$ & $140.61 * *$ & 98 \\
\hline F-test & $10.17^{* *}$ & $1.32^{\mathrm{NS}}$ & & \\
\hline \multicolumn{5}{|c|}{ Pindorama } \\
\hline $30 \mathrm{~F} 35$ & $81.0 \mathrm{AB}$ a & $19.0 \mathrm{AB} \mathrm{b}$ & $193.67 * *$ & 77 \\
\hline $2 \mathrm{~B} 710$ & $89.0 \mathrm{~A} \mathrm{a}$ & $10.0 \mathrm{BC} \mathrm{b}$ & $314.43 * *$ & 89 \\
\hline Impacto & $29.0 \mathrm{E} \quad \mathrm{a}$ & $0.0 \mathrm{C} \quad \mathrm{b}$ & $42.37 * *$ & 100 \\
\hline AG8088 & $69.0 \mathrm{BC} \mathrm{a}$ & $32.0 \mathrm{~A} \quad \mathrm{~b}$ & $68.97 * *$ & 54 \\
\hline DKB390 & $50.0 \mathrm{D}$ a & $6.0 \mathrm{BC} \mathrm{b}$ & $97.54 * *$ & 88 \\
\hline Maximus & $64.0 \mathrm{C} \mathrm{a}$ & $14.0 \mathrm{~B} \quad \mathrm{~b}$ & $125.95 * *$ & 78 \\
\hline F-test & $47.55 * *$ & $12.57 * *$ & & \\
\hline \multicolumn{5}{|c|}{ Votuporanga } \\
\hline $30 \mathrm{~F} 35$ & $86.0 \mathrm{~A} \mathrm{a}$ & $10.0 \mathrm{AB} \mathrm{b}$ & $302.31 * *$ & 88 \\
\hline 2B710 & $82.0 \mathrm{~A} \mathrm{a}$ & $18.0 \mathrm{~A} \mathrm{~b}$ & $214.38 * *$ & 78 \\
\hline Impacto & $57.0 \mathrm{~B} \mathrm{a}$ & $2.0 \mathrm{~B} \mathrm{~b}$ & $158.33 * *$ & 96 \\
\hline AG8088 & $77.0 \mathrm{~A} \mathrm{a}$ & $8.0 \mathrm{AB} \mathrm{b}$ & $249.19 * *$ & 90 \\
\hline DKB390 & $78.0 \mathrm{~A} \mathrm{a}$ & $8.0 \mathrm{AB} \mathrm{b}$ & $256.46 * *$ & 90 \\
\hline Maximus & $77.0 \mathrm{~A} \mathrm{a}$ & $3.0 \mathrm{~B} \mathrm{~b}$ & $286.61 * *$ & 96 \\
\hline F-test & $10.53 * *$ & $3.45^{*}$ & & \\
\hline
\end{tabular}

Means followed by the same uppercase letter in the columns and lowercase letter in the rows do not significantly differ from each other according to Tukey's test at a significance level of $5 \%$. ${ }^{\text {NS}}$ : not significant; ${ }^{* *}$ : significant at $1 \%$; \%Red.: percentage of reduction for $\mathrm{Bt}$ in relation to non-Bt.

As to damage scores, there was interaction between the factors (hybrids versus technologies) for all regions (Table 4). Comparing the conventional hybrids, it was observed that DKB390 and Maximus were the hybrids with less ear damages in Aguaí. In Cruzália, the DKB390 and Impacto hybrids presented the lowest damage scores.
In Pindorama, there were no significant differences among the hybrids. In Votuporanga, the AG8088 presented the lowest score for damages resulting from the presence of caterpillars in the maize ear. 
Table 4 - Score for damages resulting from caterpillar attacks for each hybrid and technology of location in the state of São Paulo, in the summer crop $(2009 / 10)$.

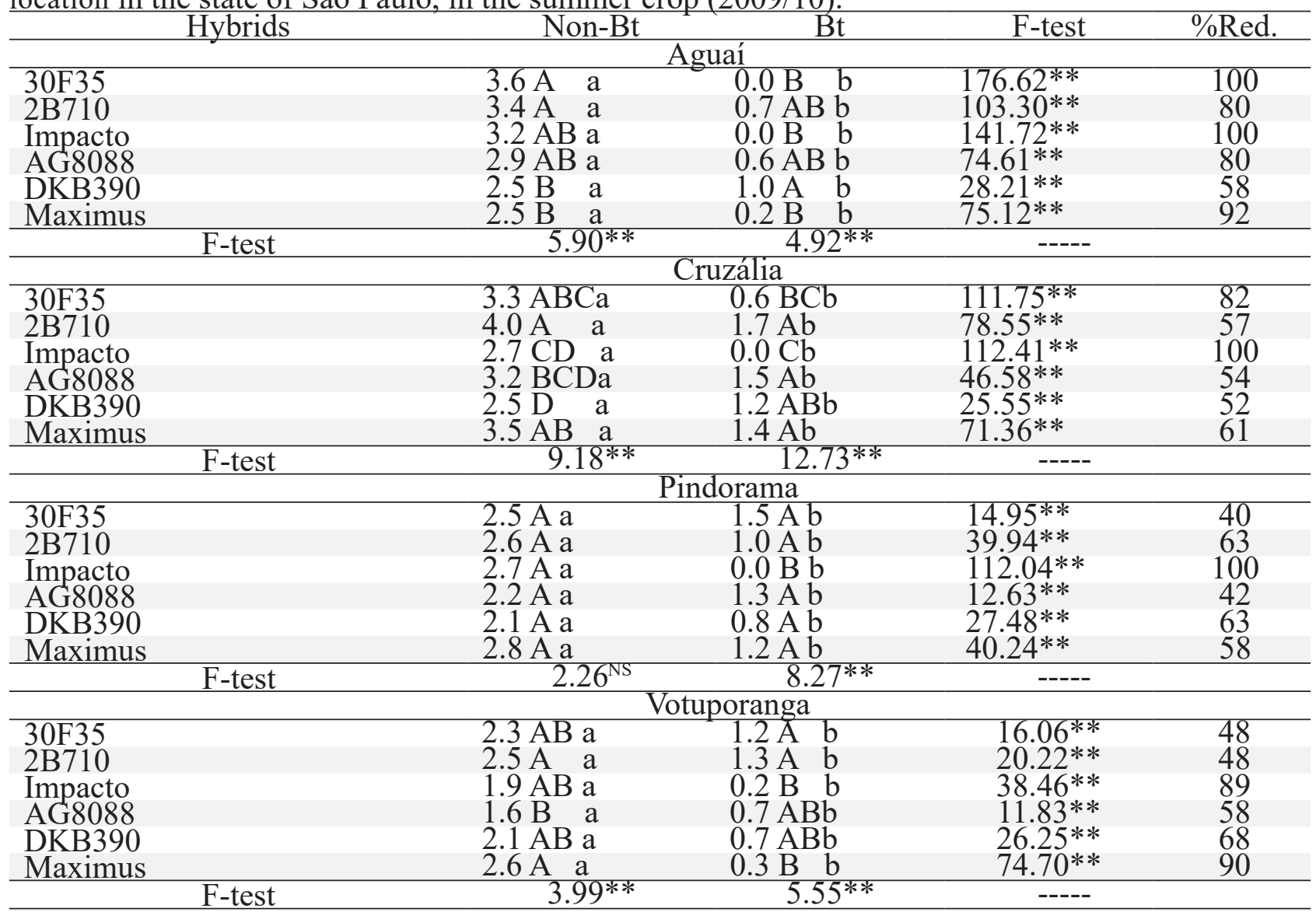

Means followed by the same uppercase letter in the columns and lowercase letter in the rows do not significantly differ from each other according to Tukey's test at a significance level of $5 \%$. ${ }^{\text {NS}}$ : not significant; **: significant at $1 \%$; $\%$ Red.: percentage of reduction for $\mathrm{Bt}$ in relation to non-Bt.

When comparing the transgenic hybrid versions (Table 4), there were low damage scores in the four locations. In Aguaí, scores varied from 0.00 to 1.04 , with highlight to Impacto TL and 30F35 Y hybrids, both expressing Cry $1 \mathrm{Ab}$ toxin, with the lowest scores (0.00), and Maximus Viptera with damage score of 0.20 .

In Cruzália, scores varied from 0.00 to 1.73, again with highlight to Impacto TL hybrid with ear damage score of 0.00 , and 30F35 Y with score of 0.60 . In Pindorama, there was a variation from 0.00 to 1.48 in ear damage score and one more time Impacto TL stood out with damage score of 0.00 .

In Votuporanga, scores ranged from 0.20 to 1.31 . Impacto TL and Maximus Viptera hybrids presented the lowest scores for ear damages. On average, regardless of the location, and considering only each hybrid, the use of genetic modification provided reduction of $68 \%$, $62 \%, 97 \%, 59 \%, 60 \%$ and $75 \%$, respectively, for the hybrids $30 \mathrm{~F} 35 \mathrm{Y}, 2 \mathrm{~B} 710 \mathrm{HX}$, Impacto 
TL, AG8088 YG, DKB390 YG and Maximus Viptera.

Percentage of damaged ears and scores for ear damages due to caterpillar attack in the second year of evaluation - Summer Crop (2010/11)

In the second year, differences in the percentage of damaged ears were significant among the hybrids, technologies and interaction between hybrids versus technologies in the four regions (Table 5).

Upon analysis of the interaction between the factors (Table 6), it was found that the percentage of ears attacked ranged from 14\% in Bts to $98 \%$ in conventional hybrids. In Aguaí, among the conventional hybrids, AG8088 and 2B710 presented the lowest percentages of damaged ears. In Cruzália, Impacto and Maximus were the hybrids less affected by caterpillar attacks in the maize ear. In Pindorama, only the Impacto hybrid stood out, with the lowest percentages of damaged ears. In Votuporanga, there were no significant differences among the hybrids. These results demonstrate great variation depending on the location where the experiment was installed. Among the hybrids using Bt technologies (Table 6), Maximus expressing VIP3Aa20 protein presented the lowest percentage of damaged ears in the four locations. Besides that hybrid, 2B710 HX expressing Cry 1F protein stood out as intermediate in Cruzália and similar to Maximus Viptera in Votuporanga. In Cruzália, Impacto $\mathrm{TL}$ expressing Cry $1 \mathrm{Ab}$ protein also presented an intermediate percentage of damaged ears between the most and least damaged hybrids.

A comparison between hybrids using $\mathrm{Bt}$ technologies and their respective conventional versions showed significant differences for all hybrids, except for 2B710/2B710 HX in Aguaí and 30F35/30F35 Y in Pindorama (Table 6). As to the other hybrids, there were reductions that varied from $16 \%$ to $78 \%$.

With respect to scores for ear damages caused by caterpillars, a significant difference was noted among the hybrids, technologies and interaction between these factors (hybrids versus technologies) in all locations, except for the interaction between those factors in Pindorama (Table 5). In that location, where there was no interaction between the factors, a significant difference was noted for one hybrid and one technology. Among the hybrids, the 30F35 was the most damaged. Between the technologies, the use of Bt provided a reduction of $43 \%$ in damage scores (Table 5).

In general, the reduction in damage scores was, on average, of $56.3 \%$ in transgenic hybrids compared with the averages in conventional hybrids, being the Víptera and Herculex the most efficient technologies (Table 7). These results are in line with the findings of Silva et al. (2018), who verified that the Cry1 $\mathrm{Ab}$ technology reduced $H$. zea damages in three out of the four experimental fields that were evaluated, and also the findings of Michelotto et al. (2017b), when assessing the efficiency of the Maximus Viptera hybrid (Vip3Aa20) in the reduction of $S$. frugiperda 
Table 5 - Summary of the analysis of variance for percentage of damaged ears (\%E) and damage scores (DS), due to caterpillar attacks, for each hybrid $(\mathrm{H})$ and technology $(\mathrm{T})$ of location in the state of São Paulo, in the summer crop (2010/11).

\begin{tabular}{|c|c|c|c|c|c|c|c|c|}
\hline & \multicolumn{2}{|c|}{ Aguaí } & \multicolumn{2}{|c|}{ Cruzália } & \multicolumn{2}{|c|}{ Pindorama } & \multicolumn{2}{|c|}{ Votuporanga } \\
\hline & $\% \mathrm{E}$ & $\mathrm{DS}$ & $\% \mathrm{E}$ & $\mathrm{DS}$ & $\% \mathrm{E}$ & $\mathrm{DS}$ & $\% \mathrm{E}$ & DS \\
\hline F-test $(\mathrm{H})$ & $2.91 *$ & $23.37 * *$ & $103.67 * *$ & $88.44 * *$ & $12.93 * *$ & $14.33 * *$ & $9.72 * *$ & $25.45^{* *}$ \\
\hline F-test (T) & $112.68 * *$ & $239.36 * *$ & $246.96 * *$ & $348.31 * *$ & $169.01 * *$ & $295.10 * *$ & $172.77 * *$ & $277.78 * *$ \\
\hline F-test $(\mathrm{H} \times \mathrm{T})$ & $7.25^{* *}$ & $27.43 * *$ & $13.05 * *$ & $22.18 * *$ & $7.83^{* *}$ & $2.06^{\mathrm{NS}}$ & $10.01 * *$ & $10.43^{* *}$ \\
\hline C.V. $(\%)$ & 25.42 & 22.74 & 11.90 & 15.61 & 13.26 & 12.53 & 16.33 & 20.25 \\
\hline
\end{tabular}

Table 6 - Percentage of ears damaged by caterpillar attacks, for each hybrid and technology of locationon in the state of São Paulo, in the summer crop (2010/11).

\begin{tabular}{|c|c|c|c|c|}
\hline Hybrids & Non-Bt & $\mathrm{Bt}$ & F-test & $\%$ Red. \\
\hline \multicolumn{5}{|c|}{ Aguaí } \\
\hline $30 \mathrm{~F} 35$ & $81.0 \mathrm{~A} \quad \mathrm{a}$ & $27.0 \mathrm{AB} \mathrm{b}$ & $48.80 * *$ & 67 \\
\hline 2B710 & $49.0 \mathrm{BC} \mathrm{a}$ & $42.0 \mathrm{~A} \mathrm{a}$ & $0.82^{\mathrm{NS}}$ & 0 \\
\hline Impacto & $69.0 \mathrm{AB}$ a & $41.0 \mathrm{~A} \quad \mathrm{~b}$ & $13.12 * *$ & 41 \\
\hline AG8088 & $45.0 \mathrm{C} \quad \mathrm{a}$ & $29.0 \mathrm{AB} b$ & $4.28 *$ & 36 \\
\hline DKB390 & $68.0 \mathrm{AB}$ a & $32.0 \mathrm{AB} \mathrm{b}$ & $21.69 * *$ & 53 \\
\hline Maximus & $77.0 \mathrm{~A} \quad \mathrm{a}$ & $17.0 \mathrm{~B} \mathrm{~b}$ & $60.24 * *$ & 78 \\
\hline F-test & $7.23 * *$ & $2.93 *$ & & \\
\hline \multicolumn{5}{|c|}{ Cruzália } \\
\hline $30 \mathrm{~F} 35$ & $96.0 \mathrm{~A} \mathrm{a}$ & $81.0 \mathrm{Ab}$ & $9.85^{* *}$ & 16 \\
\hline $2 \mathrm{~B} 710$ & $96.0 \mathrm{~A} \mathrm{a}$ & $33.0 \mathrm{Cb}$ & $173.71 * *$ & 66 \\
\hline Impacto & $65.0 \mathrm{~B} \mathrm{a}$ & $31.0 \mathrm{Cb}$ & $50.59 * *$ & 52 \\
\hline AG8088 & $93.0 \mathrm{~A} \mathrm{a}$ & $67.0 \mathrm{ABb}$ & $29.59 * *$ & 28 \\
\hline DKB390 & $91.0 \mathrm{~A} \mathrm{a}$ & $63.0 \mathrm{Bb}$ & $34.31 * *$ & 31 \\
\hline Maximus & $32.0 \mathrm{C} \mathrm{a}$ & $14.0 \mathrm{Db}$ & $14.18 * *$ & 56 \\
\hline F-test & $58.17 * *$ & $58.56 * *$ & & \\
\hline \multicolumn{5}{|c|}{ Pindorama } \\
\hline $30 F 35$ & $98.0 \mathrm{~A} \mathrm{a}$ & $88.0 \mathrm{~A} \mathrm{a}$ & $2.69^{\mathrm{NS}}$ & 0 \\
\hline 2B710 & $95.0 \mathrm{AB}$ a & $53.0 \mathrm{BC} \mathrm{b}$ & $47.53 * *$ & 44 \\
\hline Impacto & $77.0 \mathrm{~B} \quad \mathrm{a}$ & $48.0 \mathrm{BC} \mathrm{b}$ & $22.66^{* *}$ & 38 \\
\hline AG8088 & $83.0 \mathrm{AB}$ a & $47.0 \mathrm{BC} \mathrm{b}$ & $34.92 * *$ & 43 \\
\hline DKB390 & $83.0 \mathrm{AB}$ a & $64.0 \mathrm{~B} \mathrm{~b}$ & $9.73^{* *}$ & 23 \\
\hline Maximus & $97.0 \mathrm{~A} \quad \mathrm{a}$ & $39.0 \mathrm{C} \quad \mathrm{b}$ & $90.64 * *$ & 60 \\
\hline F-test & $4.28 * *$ & $16.48 * *$ & & \\
\hline \multicolumn{5}{|c|}{ Votuporanga } \\
\hline $30 \mathrm{~F} 35$ & $92.0 \mathrm{~A} \mathrm{a}$ & $64.0 \mathrm{~A} \mathrm{~b}$ & $15.36^{* *}$ & 30 \\
\hline 2B710 & $84.0 \mathrm{~A} \mathrm{a}$ & $25.0 \mathrm{~B} \mathrm{~b}$ & $68.21 * *$ & 70 \\
\hline Impacto & $83.0 \mathrm{~A} \mathrm{a}$ & $55.0 \mathrm{~A} \mathrm{~b}$ & $15.36^{* *}$ & 34 \\
\hline AG8088 & $82.0 \mathrm{~A} \mathrm{a}$ & $63.0 \mathrm{~A} \mathrm{~b}$ & $7.07 *$ & 24 \\
\hline DKB390 & $94.0 \mathrm{~A} \mathrm{a}$ & $72.0 \mathrm{~A} \mathrm{~b}$ & $9.48 * *$ & 23 \\
\hline Maximus & $95.0 \mathrm{~A} \mathrm{a}$ & $21.0 \mathrm{~B} \mathrm{~b}$ & $107.31 * *$ & 78 \\
\hline F-test & $1.39^{\mathrm{NS}}$ & $18.34 * *$ & & \\
\hline
\end{tabular}

Means followed by the same uppercase letter in the column and lowercase letter in the row do not significantly differ from each other according to Tukey's test at a significance level of 5\%. NS: not significant; **: significant at $1 \% ; \%$ Red.: percentage of reduction for $B t$ in relation to non- $B t$. 
Table 7 - Score for ear damage caused by caterpillars for each hybrid and technology of location in the state of São Paulo, in the summer crop (2010/11).

\begin{tabular}{|c|c|c|c|c|}
\hline Hybrids & Non-Bt & $\mathrm{Bt}$ & F-test & $\%$ Red. \\
\hline \multicolumn{5}{|c|}{ Aguaí } \\
\hline 30F35 & $2.2 \mathrm{~A} \mathrm{a}$ & $0.5 \mathrm{AB} \mathrm{b}$ & $234.12 * *$ & 79 \\
\hline 2B710 & $0.6 \mathrm{D} a$ & $0.5 \mathrm{AB} a$ & $0.39^{\mathrm{NS}}$ & 0 \\
\hline Impacto & $1.0 \mathrm{BC} \mathrm{a}$ & $0.5 \mathrm{~A} \mathrm{~b}$ & $17.448 * *$ & 47 \\
\hline AG8088 & $0.9 \mathrm{CD} a$ & $0.5 \mathrm{~A} \mathrm{~b}$ & $9.15 * *$ & 40 \\
\hline DKB390 & $1.0 \mathrm{BC} \mathrm{a}$ & $0.4 \mathrm{AB} \mathrm{b}$ & $31.41 * *$ & 61 \\
\hline Maximus & $1.2 \bar{B} \quad \mathrm{a}$ & $0.2 \mathrm{~B} \quad \mathrm{~b}$ & $83.96 * *$ & 86 \\
\hline \multicolumn{5}{|c|}{$47.92 * *$} \\
\hline \multicolumn{5}{|c|}{ Cruzália } \\
\hline $30 \mathrm{~F} 35$ & $2.3 \mathrm{~A} \mathrm{a}$ & $1.5 \mathrm{Ab}$ & $32.54 * *$ & 33 \\
\hline $2 \mathrm{~B} 710$ & $2.6 \mathrm{Aa}$ & $0.4 \mathrm{~B} \mathrm{~b}$ & $269.63 * *$ & 84 \\
\hline Impacto & $1.1 \mathrm{~B} \mathrm{a}$ & $0.5 \mathrm{~B} \mathrm{~b}$ & $23.59 * *$ & 55 \\
\hline $\mathrm{AG} 8088$ & $2.2 \mathrm{~A} \mathrm{a}$ & $1.2 \mathrm{Ab}$ & $63.05 * *$ & 47 \\
\hline DKB390 & $2.2 \mathrm{Aa}$ & $1.2 \mathrm{Ab}$ & $61.83 * *$ & 47 \\
\hline Maximus & $0.5 \mathrm{Ca}$ & $0.1 \mathrm{~B} \mathrm{~b}$ & $8.58 * *$ & 75 \\
\hline F-test & $75.73 * *$ & $34.88^{* *}$ & & \\
\hline \multicolumn{5}{|c|}{ Votuporanga } \\
\hline $30 \mathrm{~F} 35$ & $2.8 \mathrm{~A} \mathrm{a}$ & $1.3 \mathrm{Ab}$ & $86.29 * *$ & 45 \\
\hline 2B710 & $1.3 \mathrm{C} \mathrm{a}$ & $0.3 \mathrm{~B} \mathrm{~b}$ & $34.31 * *$ & 89 \\
\hline Impacto & $.5 \mathrm{Ca}$ & $0.8 \mathrm{Ab}$ & $15.71 * *$ & 46 \\
\hline AG8088 & $.5 \mathrm{Ca}$ & $1.0 \mathrm{Ab}$ & $9.83 * *$ & 36 \\
\hline DKB390 & $2.1 \mathrm{~B} \mathrm{a}$ & $1.0 \mathrm{Ab}$ & $47.92 * *$ & 55 \\
\hline Maximus & $2.2 \mathrm{~B} \mathrm{a}$ & $0.2 \mathrm{~B} \mathrm{~b}$ & $135.86 * *$ & 89 \\
\hline
\end{tabular}

Means followed by the same uppercase letter in the column and lowercase letter in the row do not significantly differ from each other according to Tukey's test at a significance level of $5 \%$. ${ }^{\text {NS}}$ : not significant; **: significant at $1 \%$; $\%$ Red.: percentage of reduction for Bt in relation to non-Bt.

damages.

Comparison of Bt technologies for percentage of damaged ears and scores for ear damages caused by caterpillars in the second year of evaluationSummer Crop (2010/11)

Upon analysis of conventional hybrids with the distinct $\mathrm{Bt}$ technologies, it was found that the percentage of damaged ears for the 30F35 hybrid was reduced when the two $\mathrm{Bt}$ technologies were used. This event happened in all locations, except in Votuporanga where there was no significant difference among the hybrids. Moreover, damage scores also presented significant reductions, even in Votuporanga. Similar response was obtained for the AG8088 hybrid when compared with AG8088 YG and AG 8088 VTPRO. In this case, differences were also observed in Votuporanga, with VTPRO being the technology that was less affected by the presence of caterpillars. It shall be pointed out that the VTPRO technology, which expresses Cry1A.105 + Cry $2 \mathrm{Ab} 2$ protein, was the most responsive, even when compared with the AG8088 YG (Cry $1 \mathrm{Ab})$ technology. As to the DKB 390 hybrid, the use of genetic modification provided the best results, regardless of the technology applied (YG or PRO), with significant reduction in the percentage of damaged ears and damages by 
caterpillar (Table 8).

provided the lowest percentages of damaged ears

According to the responses shown in and lowest damage scores (Table 8). Michelotto

Table 8, it was observed that Cry $1 \mathrm{~F}(30 \mathrm{~F} 35 \mathrm{H})$ et al. (2017b) found similar responses in the and Cry 1A.105+Cry2Ab2 (AG8088 VTPRO control of $S$. frugiperda with the use of hybrids and DKB390 PRO) were the technologies that that express Cry1F, Cry1A105 and VIP3Aa20

Table 8 - Percentage of damaged ears (\%E) and damage scores (DS), due to caterpillar attacks, for each hybrid and Bt technology in the different locations in the state of São Paulo, in the summer crop (2010/11).

\begin{tabular}{|c|c|c|c|c|c|c|c|c|}
\hline \multirow{2}{*}{ Hybrids (H) } & \multicolumn{2}{|c|}{ Aguaí } & \multicolumn{2}{|c|}{ Cruzália } & \multicolumn{2}{|c|}{ Pindorama } & \multicolumn{2}{|c|}{ Votuporanga } \\
\hline & $\% \mathrm{E}$ & DS & $\% \mathrm{E}$ & DS & $\% \mathrm{E}$ & DS & $\% \mathrm{E}$ & DS \\
\hline \multicolumn{9}{|c|}{ Hybrid 1} \\
\hline $30 \mathrm{~F} 35$ & $81.0 \mathrm{~A}$ & $2.2 \mathrm{~A}$ & $96.0 \mathrm{~A}$ & $2.3 \mathrm{~A}$ & $98.0 \mathrm{~A}$ & $3.4 \mathrm{~A}$ & $92.0 \mathrm{~A}$ & $2.8 \mathrm{~A}$ \\
\hline $30 \mathrm{~F} 35 \mathrm{Y}$ & $27.0 \mathrm{~B}$ & $0.5 \mathrm{~B}$ & $81.0 \mathrm{~B}$ & $1.5 \mathrm{~B}$ & $88.0 \mathrm{~B}$ & $2.0 \mathrm{~B}$ & $64.0 \mathrm{~A}$ & $1.3 \mathrm{~B}$ \\
\hline $30 \mathrm{~F} 35 \mathrm{H}$ & $26.0 \mathrm{~B}$ & $0.6 \mathrm{~B}$ & $58.0 \mathrm{C}$ & $1.0 \mathrm{C}$ & $83.0 \mathrm{~B}$ & $2.0 \mathrm{~B}$ & $54.0 \mathrm{~A}$ & $1.0 \mathrm{~B}$ \\
\hline F-test & $34.05 * *$ & $79.45^{* *}$ & $37.90^{* *}$ & $60.41 * *$ & $14.00 * *$ & $298.88 * *$ & $3.34 \mathrm{NS}$ & $21.45^{* *}$ \\
\hline C.V. $(\%)$ & 27.00 & 22.39 & 8.88 & 11.99 & 5.09 & 4.40 & 34.45 & 28.82 \\
\hline \multicolumn{9}{|c|}{ Hybrid 2} \\
\hline AG8088 & $45.0 \mathrm{~A}$ & $0.9 \mathrm{~A}$ & $93.0 \mathrm{~A}$ & $2.2 \mathrm{~A}$ & $83.0 \mathrm{~A}$ & $2.7 \mathrm{~A}$ & $82.0 \mathrm{~A}$ & $1.5 \mathrm{~A}$ \\
\hline AG8088 YG & $29.0 \mathrm{~B}$ & $0.5 \mathrm{~B}$ & $67.0 \mathrm{~B}$ & $1.2 \mathrm{~B}$ & $47.0 \mathrm{~B}$ & $1.6 \mathrm{~B}$ & $63.0 \mathrm{~A}$ & $1.0 \mathrm{~B}$ \\
\hline AG8088 VTPRO & $15.0 \mathrm{C}$ & $0.2 \mathrm{C}$ & $46.0 \mathrm{C}$ & $0.7 \mathrm{C}$ & $45.0 \mathrm{~B}$ & $1.4 \mathrm{~B}$ & $29.0 \mathrm{~B}$ & $0.4 \mathrm{C}$ \\
\hline F-test & $21.81^{* *}$ & $36.84 * *$ & $42.37^{* *}$ & $45.48^{* *}$ & $13.79 * *$ & $13.36^{* *}$ & $27.29 * *$ & $50.02 * *$ \\
\hline C.V. $(\%)$ & 24.23 & 22.54 & 11.78 & 18.91 & 22.08 & 21.86 & 19.82 & 18.57 \\
\hline \multicolumn{9}{|c|}{ Hybrid 3} \\
\hline DKB390 & $68.0 \mathrm{~A}$ & $1.3 \mathrm{~A}$ & $91.0 \mathrm{~A}$ & $2.2 \mathrm{~A}$ & $83.0 \mathrm{~A}$ & $2.6 \mathrm{~A}$ & $94.0 \mathrm{~A}$ & $2.1 \mathrm{~A}$ \\
\hline DKB390 YG & $32.0 \mathrm{~B}$ & $0.4 \mathrm{~B}$ & $63.0 \mathrm{~B}$ & $1.2 \mathrm{~B}$ & $64.0 \mathrm{~B}$ & $1.6 \mathrm{~B}$ & $72.0 \mathrm{~B}$ & $1.0 \mathrm{~B}$ \\
\hline DKB390 PRO & $28.0 \mathrm{~B}$ & $0.4 \mathrm{~B}$ & $57.0 \mathrm{~B}$ & $1.2 \mathrm{~B}$ & $47.0 \mathrm{C}$ & $1.6 \mathrm{~B}$ & $36.0 \mathrm{C}$ & $0.6 \mathrm{~B}$ \\
\hline F-test & $11.33^{* *}$ & $16.87 * *$ & $24.40^{* *}$ & $50.66^{* *}$ & $44.74 * *$ & $35.40 * *$ & $29.14 * *$ & $32.50^{* *}$ \\
\hline C.V. $(\%)$ & 34.29 & 33.81 & 11.68 & 12.08 & 9.31 & 11.22 & 18.00 & 25.71 \\
\hline
\end{tabular}

Means followed by the same letter, in the column, do not significantly differ according to Tukey's test at a significance level of 5\%. NS: not significant; *: significant at 5\%; **: significant at 1\%; C.V. (\%): coefficient of variation. 
proteins. In the comparison made in the present study, it was found that the Cry1 Ab technologies, even though reducing the percentage of damaged ears and the average value of damages caused by caterpillars, were not as efficient as the other technologies in the same hybrid, mainly in comparison with hybrids that express Cry 1A. $105+$ Cry2Ab2 protein. A previous study carried out by Sousa et al. (2016) demonstrated that maize expressing $\mathrm{Cry} 1 \mathrm{Ab}$ protein does not meet the condition of high dose for fall armyworm. Buntin (2008), when assessing the MON810 (Cry1Ab) and TC1507 (Cry1F) events for protection against damages caused by $S$. frugiperda, verified damage reduction in areas with low and moderate infestation levels. However, the author points out that, in high infested areas, hybrids with $\mathrm{Cry} 1 \mathrm{Ab}$ protein suffered more attacks than those with CrylF technology. These results, which were found for fall armyworm, show similarity with the ones found for caterpillars attacking maize ears with regard to the Cry $1 \mathrm{Ab}$ technology. Evaluations demonstrated great variability among the hybrids, even among those which express the same proteins, such as AG8088 YG (Cry 1Ab), DKB390 YG (Cry 1Ab), Impacto TL (Cry 1Ab) and 30F35 Y (Cry 1Ab).

Transgenic hybrids, regardless of the year, significantly reduced the percentages of damaged ears and scores for ear damages caused by caterpillars in all locations, which demonstrates the great efficiency of Bt proteins in the control of caterpillar pests in maize ear.
Duarte et al. (2007) found that the percentage of ears damaged by caterpillar was of $35.4 \%$ in nonBt maize hybrids, while Bt hybrids presented no damaged ears. In the present study, it was found that the percentages of damaged ears varied from $0 \%$ (Bt) to $98 \%$ (conventional), depending on the hybrid, the location and the year. Silva et al. (2018) mentioned that the Bt technology can be a useful tool to control H. zea; however, the level of Cry $1 \mathrm{Ab}$ toxin produced in MON 810 maize tissues, where the larvae feed themselves, may be insufficient, depending on the pest infestation level. Moreover, along the years, the technology efficiency may change (Omoto et al., 2016). According to Kaur etal.(2019), H. zea populations resistant to Cry1A105/Cry2AB2 protein have been identified in the United States. Michelotto et al. (2017a) found that the YieldGard, Herculex and Total Liberty technologies quickly lost their efficiency in the control of fall armyworm, and the VTPRO technology lost $50 \%$ of its efficiency after 5 years of use. Nevertheless, the Viptera 3 technology has been keeping its efficiency in the control of S. frugiperda in the state of São Paulo since 2012.

The wide utilization of transgenic crops has caused an increase in the selection pressure and in the risks associated with development of Bt toxin resistance in insects (Hutchinson, 2015). Cases of insects that are resistant to Bt proteins have already been reported in many parts of the world, including Brazil and Puerto Rico, with $S$. frugiperda resistant to Cry1F protein (Waquil et al., 2016; Farias et al., 2014; Storer 
et al., 2010); in South Africa, with Busseola fusca (Fuller) (Lepidoptera: Noctuidae) resistant to Cry $1 \mathrm{Ab}$ protein (Van Rensburg, 2007); in India, with Pectinophora gossypiella (Saunders) (Lepidoptera: Gelechiidae) resistant to Cry1Ac toxin, among others.

Cases of H. zea resistance to Bt protein have already been reported for Cry1Ac and Cry2Ab events in the USA (Tabashnik et al., 2008; Tabashnik \& Carrière, 2010). According to Leite et al. (2018), the resistance can evolve very quickly. In less than 5 years, $S$. frugiperda presented resistance to maize with Cry $1 \mathrm{~F}$ toxin (Farias et al., 2014, Leite et al., 2016) and with Cry1 Ab (Omoto et al., 2016).

In the present study, it was observed that, among the conventional hybrids, Impacto, Maximus, DKB390 and 2B710 were the ones that presented lower ear damages by caterpillars. Moraes et al. (2015) verified that Impacto and Maximus hybrids presented less yield reduction when infested by S. frugiperda. As to Bt hybrids, they were the most efficient, providing reductions of up to $62 \%$, on average, in comparison with conventional hybrids, regardless of the season crop and technology applied.

In general, this study demonstrated that all of the Bt hybrids evaluated presented lower ear damage caused by caterpillar. Therefore, even if there is occurrence of $S$. frugiperda populations in the field that are resistant to some of these proteins, it is important that they are maintained in commercial hybrids because they provide protection against ear damages and contribute to the management of resistance by caterpillar pests that attack maize ears. However, upon the release of Bt technologies, combining several insecticidal proteins, and the growing number of cases of insect resistance to transgenic technologies and insecticides, frequent evaluations are required with the aim of monitoring the evolution of insect resistance in these hybrids and others with Bt technologies, in order to guide the integrated management in areas with high incidence of those insects.

\section{Conclusions}

All Bt technologies present in maize, YieldGard (Cry 1Ab), Total Liberty (Cry 1Ab), Herculex (Cry 1F), VTPRO (Cry 1A.105+Cry2Ab2), and Viptera (Vip3Aa20), reduce ear damages caused by caterpillars, regardless of the genetic basis of the hybrid, the location and the year.

Among Bt technologies, the Viptera expressing Vip3Aa20 protein is the most efficient for control of caterpillars in maize ears.

Hybrids that express Cry $1 \mathrm{Ab}$ protein are less efficient than the other technologies for control of caterpillars in maize ears.

Among the conventional versions, the Impacto hybrid is the least sensitive to caterpillars in maize ear; followed by Maximus, DKB 390 and $2 \mathrm{~B} 710$, in contrast to $30 \mathrm{~F} 35$ and AG8088 hybrids. 


\section{Acknowledgements}

The authors thank the São Paulo Research Foundation (Fundação de Amparo à Pesquisa FAPESP, Proc. No. 2010/02666-8) for the project financial support; the Brazilian National Council for Scientific and Technological Development (Conselho Nacional de Desenvolvimento Cientifico e Tecnológico) for the research productivity scholarship granted to the first author.

\section{References}

BARBOSA, J. C.; MALDONADO JUNIOR, W. 2015. AgroEstat - sistema para análises Estatísticas de ensaios agronômicos. Jaboticabal: FCAV/UNESP. 396p.

BUNTIN, G. D. Corn expressing CrylAb or Cry1F endotoxin for fall armyworm and corn earworm (Lepidoptera: Noctuidae) management in field corn for grain production. Florida Entomologist, v. 91, n. 4, p. 523-530, 2008. DOI: $10.1653 / 0015-4040-91.4 .523$

CARVAlHO, R. L. P. Pragas do milho. In: PATERNIANI, E. (Ed.). Melhoramento e produção de milho no Brasil. Piracicaba: Fundação Camgiii, 1980. p505--570.

\section{CÉLERES, 2018. $3^{\circ}$ levantamento de adoção} da biotecnologia agrícola no Brasil, safra 2016/17. http://www.celeres.com.br. Acesso em
16 de abril de 2018.

COMISSÃO TÉCNICA NACIONAL DE BIOSSEGURANÇA - CTNBio. Liberação comercial. Available in: <http://ctnbio.mcti.gov. br/liberacao-comercial\#/liberacao-comercial/ consultar-processo>. Access in: 19 fev. 2018.

CZEPAK, C.; ALBERNAZ, K. C.; VIVAN, L. M.; GUIMARÃES, H. O.; CARVALHAIS, T. Primeiro registro de ocorrência de Helicoverpa armigera (Hübner) (Lepidoptera: Noctuidae) no Brasil. Pesquisa Agropecuária Tropical, v. 43, n. 1, p. 110-113, 2013.

DOI: 10.1590/S1983-40632013000100015.

DIVELY, G. P.; VENUGOPAL, P. D.; FINKENBINDER, C. Field-evolved resistance in corn earworm to Cry proteins expressed by transgenic sweet corn. PloS one, v. 11, n. 12, p. 0169115, 2016. DOI: 10.1371/journal. pone. 0169115

DUARTE, J. M.; GOMES, M. S.; SALDANHA, L. A.; ARGENTA, G.; RAMBO, L. Eficácia de híbridos de milho Bt11 no controle de lepidópteros-praga em condições de campo sob infestação natural. 2007. Disponível em: http://www.syngenta.com.br/cs/Resumo $\% 20$ expandido\%20milho\%20Bt11.pdf. Acesso em: 10/02/2009.

FARIAS, J. R.; ANDOW, D. A.; HORIKOSHI, R. J.; SORGATTO, R. J.; FRESIA, P.; DOS 
SANTOS, A. C.; OMOTO, C. Field-evolved resistance to Cry1F maize by Spodoptera frugiperda (Lepidoptera: Noctuidae) in Brazil. Crop protection, v. 64, p. 150-158, 2014.

DOI: $10.1016 /$ j.cropro.2014.06.019

GALLO, D.; NAKANO, O.; SILVEIRA NETO, S.; CARVALHO, R. P. L.; BATISTA, G. C.; BERTI FILHO, E.; PARRA, J. R. P.; ZUCCHI, R. A.; ALVES, S. B.; VENDRAMIN, J. D.; MARCHINI, L. C.; LOPES, J. R. S.; OMOTO, C. Entomologia Agrícola. Piracicaba: FEALQ, 2002. $920 \mathrm{p}$.

HELICOVERPA zea. In: CABI INTERNATIONAL. Invasive species compendium. Wallingford, 2018. Available in: $<$ https://www.cabi.org/isc/datasheet/26776>. Access in: 16 abr. 2018.

HUTCHINSON, W. D. Insect resistance management and integrated pest management for Bt crops: prospects for an area-wide view. In $\mathrm{Bt}$ resistance: characterization and strategies for GM crops producing Bacillus thuringiensis toxins (eds M Soberon, Y Gao, A Bravo), pp. 186-201. Wallingford, UK: CAB International, 2015.

KAUR, G.; GUO, J.; BROWN, S.; HEAD, G. P.; PRICE, P. A.; PAULA-MORAES, S.; NI, X.; DIMASE, M.; HUANG, F. Field-evolved resistance of Helicoverpa zea (Boddie) to transgenic maize expressing pyramided Cry1A.
$105 /$ Cry2Ab2 proteins in northeast Louisiana, the United States. Journal of Invertebrate Pathology, v. 163, p. 11-20, 2019.

10.1016/j.jip.2019.02.007.

LEITE, N. A.; MENDES, S. M.; SANTOSAMAYA, O. F.; SANTOS, C. A.; TEIXEIRA, T. P.; GUEDES, R. N.; PEREIRA, E. J. Rapid selection and characterization of Cry1F resistance in a Brazilian strain of fall armyworm. Entomologia Experimentalis et Applicata, v. 158, n. 3, p. 236-247, 2016.

DOI: 10.1111/eea.12399

LEITE, N. A.; PEREIRA, R. M.; DURIGAN, M. R.; AMADO, D.; FATORETTO, J.; MEDEIROS, F. C. L.; OMOTO, C. Susceptibility of Brazilian Populations of Helicoverpa armigera and Helicoverpa zea (Lepidoptera: Noctuidae) to Vip3Aa20. Journal of economic entomology, $\mathrm{v}$. 111, n. 1, p. 399-404, 2018. DOI: 10.1093/jee/ tox336

MICHELOTTO, M. D.; CROSARIOL NETO, J.; PIROTTA, M. Z.; DUARTE, A. P.; FEITAS, R. S. D.; FINOTO, E. L. Efficacy of transgenic maize insecticide treatment to control fall armyworm in late-season maize in São Paulo state, Brazil. Ciência e Agrotecnologia, v. 41, n. 2, p. 128-138, 2017b. DOI: 10.1590/141370542017412020816

MiChelotTO, M. D.; DUARTE, A. P.; DE FREITAS, R. S.; MIGUEL, F. B.; NETTO, J. 
C. Controle da lagarta-do-cartucho em milho transgênico na safrinha em São Paulo: dez anos de uso. Nucleus, edição especial, p. 67-74, 2017a. Edição especial.

MORAES, A. R. A.; LOURENÇÃO, A. L.; PATERNIANI, M. E. A. G. Z. Resistência de híbridos de milho convencionais e isogênicos transgênicos a Spodoptera frugiperda (Lepidoptera: Noctuidae). Bragantia, v. 74, n. 1, p. 50-57, 2015. DOI: $10.1590 / 1678-4499.0367$

OLIVEIRA, C. M.; AUAD, A. M.; MENDES, S. M.; FRIZZAS, M. R. Crop losses and the economic impact of insect pests on Brazilian agriculture. Crop Protection, v. 56, n. 1, p. 50-54, 2014. DOI: 10.1016/j.cropro.2013.10.022

OLMSTEAD, D. L.; NAULT, B. A.; SHELTON, A. M. Biology, ecology, and evolving management of Helicoverpa zea (Lepidoptera: Noctuidae) in sweet corn in the United States. Journal of economic entomology, v. 109, n. 4, p. 1667-1676, 2016. DOI: 10.1093/jee/tow125

OMOTO, C.; BERNARDI, O.; SALMERON, E.; SORGATTO, R. J.; DOURADO, P. M.; CRIVELLARI, A; HEAD, G. P. Field-evolved resistance to Cry1Ab maize by Spodoptera frugiperda in Brazil. Pest Management Science, v. 72, n. 9, p. 1727-1736, 2016. DOI: 10.1002/ ps.4201
OTA, E.C.; LOURENÇÃO, A.L.; DUARTE, A.P. Desempenho de cultivares de milho em relação à lagarta-do-cartucho. Bragantia, Campinas, v. 70, n. 4, p.850-859, 2011. DOI: 10.1590/S000687052011000400018 .

SANTOS, C. A.; MARUCCI, R. C.; BARBOSA, T.A. N.; ARAUJO, O. G.; WAQUIL, J. M.; DIAS, A. S.; ... MENDES, S. M. Desenvolvimento de Helicoverpa spp. em milho Bt com expressão de diferentes proteínas. Pesquisa Agropecuária Brasileira, v. 51, n. 5, p. 537-544, 2016. DOI: 10.1590/S0100-204X2016000500014.

SILVA, G. A.; PICANÇO, M. C.; FERREIRA, L. R.; FERREIRA, D. O.; FARIAS, E. S.; SOUZA, T. C.; SILVA, N. R.; PEREIRA, E. J. G. Yield Losses in Transgenic Cry1 Ab and Non-Bt Corn as Assessed Using a Crop-Life-Table Approach. Journal of Economic Entomology, v. 111, n.1, p. 218-226, 2018. DOI: 10.1093/jee/tox346

SOUSA, F. F.; MENDES, S. M.; SANTOSAMAYA, O. F.; ARAÚJO, O. G.; OLIVEIRA, E. E.; PEREIRA, E. J. G. Life-history traits of Spodoptera frugiperda populations exposed to low-dose Bt corn. PLoS One, v. 11, n. 5, p. e0156608, 2016 DOI: 10.1371/journal. pone. 0156608

SPECHT, A.; SOSA-GÓMEZ, D.R.; PAULAMORAES, S.V. de; YANO, S.A.C. Identificação morfológica e molecular de Helicoverpa armigera (Lepidoptera: Noctuidae) e ampliação de seu registro de ocorrência no Brasil. 
Pesquisa Agropecuária Brasileira, v. 48, VAN RENSBURG, J. B. J. First report of field n. 6, p.689-692, 2013. DOI: 10.1590/S0100- resistance by the stem borer, Busseola fusca 204X2013000600015.

(Fuller) to Bt-resistance maize. South African Journal of Plant and Soil, v. 24, n. 3, p. 147-151, STORER, N. P.; BABCOCK, J. M.; SCHLENZ， 2007. DOI: 10.1080/02571862.2007.10634798 M.; MEADE, T.; THOMPSON, G. D.; BING, J. W.; HUCKABA, R. M. Discovery and characterization of field resistance to $\mathrm{Bt}$ maize: Spodoptera frugiperda (Lepidoptera: Noctuidae) in Puerto Rico. Journal of economic entomology, v. 103, n. 4, p. 1031-1038, 2010. DOI: $10.1603 / \mathrm{EC} 10040$

UNITED STATES DEPARTMENT OF AGRICULTURE. World agricultural production. Washington, 2017. (Circular Series WAP 5-20). Available in: <https://apps.fas.usda. gov/psdonline/circulars/production.pdf $>$. Access in: 3 jan. 2018.

TABASHNIK, B. E.; CARRIÈRE, Y. Fieldevolved resistance to Bt cotton: bollworm in the US and pink bollworm in India. Southwestern Entomologist, v. 35, n. 3, p. 417-424, 2010. DOI: $10.3958 / 059.035 .0326$

WAQUIL, M. S.; PEREIRA, E. J. G.; DE SOUSA CARVALHO, S. S.; PITTA, R. M.; WAQUIL, J. M.; MENDES, S. M. Índice de adaptação e tempo letal da lagarta-do-cartucho em milho Bt. Pesquisa Agropecuária Brasileira, v. 51, n. 5, p. 563-570, 2016. DOI: 10.1590/S0100-

TABASHNIK, B. E.; GASSMANN, A. J.; 204X2016000500017

CROWDER, D. W.; CARRIÈRE, Y. Field evolved resistance to Bt toxins-reply. Nature Biotechnology, v. 26, n. 10, p. 1074-1076, 2008. DOI: $10.1038 / \mathrm{nbt} 1008-1074$ 